\title{
MODEL PENGEMBANGAN KARAKTER SANTRI DI PESANTREN PERSIS 67 BENDA TASIKMALAYA JAWA BARAT
}

\section{MODEL DEVELOPMENT OF SANTRI CHARACTER IN PESANTREN PERSIS 67 BENDA TASIKMALAYA WEST JAVA}

\author{
Moh. Dulkiah \\ Universitas Islam Negeri Sunan Gunung Djati Bandung \\ Jl. AH. Nasution 105 Bandung \\ Email: moh.dulkiah@uinsgd.ac.id \\ Muhamad Dachlan \\ Balai Penelitian dan Pengembangan Agama Makasar \\ Jl. A.P. Pettarani No. 72 Makasar \\ Email: Muhdachlan1970@gmail.com
}

Naskah diterima tanggal 18 Januari 2018. Naskah direvisi tanggal 1 Februari 2018. Naskah disetujui tanggal 18 Mei 2018

\begin{abstract}
Abstrak
Penelitian ini bertujuan untuk mendeskripsikan model pengembangan karakter santri di Pesantren Persis 67 Benda Tasikmalaya Jawa Barat. Metode pengumpulan data yang digunakan menggunakan penelitian lapangan dengan pendekatan kualitatif dengan penggalian data secara observasi dan wawancara mendalam (indepth interview). Hasil penelitian menunjukan bahwa: Pertama, pengembangan karakter santri terletak pada proses pengajaran, pembiasaan, dan penegakan aturan. Kedua, model pengajaran memberikan pengembangan bukan hanya pada kurikulum yang menggabungkan antara muatan kurikulum kementerian agama, muatan kurikulum kementerian pendidikan dan kebudayaan, dan muatan kurikulum lokal, tetapi juga harus mengandung prinsip-prinsip yang diperhatikan para ustadz dalam pengembangan kurikulum, yaitu: prinsip relevansi (kedekatan hubungan antara materi pembelajaran dan fenomena yang terjadi), prinsip fleksibilitas (kurikulum yang dikembangkan harus memilki ruang gerak yang memberikan kebebasan dalam bertindak, memilih program pendidikan, dan fleksibilitas dalam pengembangan program pembelajaran), prinsip efisiensi (usaha, biaya, waktu, dan tenaga yang digunakan dalam proses pembelajaran harus ketat), prinsip efektivitas (perencanaan kurikulum dapat dicapai sesuai dengan keinginan yang telah ditentukan), prinsip kesinambungan (pengembangan kurikulum menunjukkan adanya hubungan antara tingkat pendidikan, jenis pendidikan, program pendidikan dan bidang studi). Ketiga, pembiasaan diorientasikan guna menerapkan nilai kemandirian dan nilai tanggung jawab. Keempat, penegakkan aturan diimplementasikan bukan untuk memberikan sanksi fisik, melainkan lebih bersifat motivasional.
\end{abstract}

Kata Kunci : model pengembangan, karakter, santri, pesantren,

\begin{abstract}
This study aims to describe the model of santri character development in Pesantren Persis 67 Benda Tasikmalaya West Java. Data collection method used in field research with the qualitative approach with observation data and in-depth interview. The results showed that: First, santri character development lies in the process of teaching, habituation, and enforcement of rules. Secondly, the teaching model provides development not only in the curriculum that combines the curriculum content of the ministry of religions, the curriculum content of the ministries of education and culture, and the content of the local curriculum, but also contains principles that the ustadz consider in curriculum development, namely: the proximity of the relationship between the learning material and the occurring phenomenon), The principle of flexibility (the developed curriculum must have the space for freedom of action, choosing the educational program, and the flexibility in the development of the learning program), the efficiency principle (effort, cost, time, which is used in the learning process must be strict), the principle of effectiveness (curriculum planning can be achieved in accordance with the intended desire), The principle of continuity (curriculum development shows the relationship between education level, type of education, education program and field of study). Third, habituation is oriented to apply the value of independence and the value of responsibility. Fourth,
\end{abstract}


enforcement of rules is implemented not to give physical sanctions, but rather more motivational.

Keyword: model development, character, student, pesantren,

\section{PENDAHULUAN}

$\mathrm{P}$ eningkatan kualitas pendidikan karakter saat ini menjadi prioritas pemerintah terhadap seluruh satuan pendidikan baik negeri maupun swasta. Upaya tersebut diaplikasikan untuk meminimalisir prilaku-prilaku negatif dan menyimpang (deviant) remaja akibat paparan informasi tidak terkendali dan arus globalisasi. Gejala kenakalan remaja (juvenile delikuensi) semakin menohok berupa pergaulan bebas, penyalahgunaan obat terlarang, geng motor, menonton film porno, bahkan terkena HIV/AIDS. Kenakalan remaja bahkan mengarah pada adanya kekerasan (violent) dan kerusakan (decstructive) yang meresahkan masyarakat serta menjurus pada tindakan kriminalitas.

Fenomena kenakalan remaja pada satuan lembaga pendidikan menunjukkan adanya degradasi dan krisis moral yang dialami bangsa ini. Lebih tragis lagi, bila fenomena ini menyasar ke semua lembaga satuan pendidikan, termasuk institusi pesantren. Penelitian Sarbini di Tasikmalaya Jawa Barat menyebutkan bahwa terdapat fenomena degradasi moral di kalangan santri santri yang tidak menetap di pesantren (kalong), termasuk penggunaan NAPZA (narkotika penggunaan zat adiptif) sehingga pihak pesantren memberlakukan semua santri untuk diasramakan (boarding). Selain itu, terdapat tindakan pencurian, merokok, (Sarbini, 2017).

Upaya yang dilakukan dalam mengatasi krisis moral adalah menerapkan pengembangan karakter. Dalam sistem pendidikan pengembangan karakter merupakan hubungan antara komponenkomponen karakter yang mengandung nilai-nilai perilaku dan saling berkaitan antara pengetahuan nilai-nilai perilaku dengan sikap atau emosi yang kuat untuk melaksanakannya, baik terhadap Allah SWT, lingkungan, keluarga, maupun dirinya sendiri. Pengembangan karakter diperluas dalam bentuk pendidikan karakter. Sementara pendidikan karakter merupakan investasi nilai kultural yang membangun watak, moralitas dan kepribadian masyarakat yang dilakukan dalam waktu panjang, kontinyu, intens, konstan dan konsisten.

Pendidikan sendiri dinilai bukan hanya mencakup proses transfer atau transmisi ilmu pengetahuan, melainkan juga merupakan proses strategis dalam menanamkan nilai-nilai kepada peserta didik. Ahmad Tafsir menyatakan bahwa nilai-nilai yang terkandung dalam tujuan pendidikan diorientasikan untuk meningkatkan kemampuan potensi seseorang agar menjadi manusia yang beriman, bertaqwa, berakhlakul karimah, sehat, berilmu, cakap, kreatif, mandiri, serta menjadi warga negara yang demokratis dan bertanggung jawab (Tafsir, 1991). Pernyataan senada juga diungkapkan oleh Azra (2008:42), bahwa suatu pendidikan tidak hanya mencetak peserta didik yang unggul dalam ilmu pengetahuan dan teknologi an sich, namun juga dapat mengembangkan jati diri, karakter, dan kepribadiannya.

Begitu pentingnya pendidikan karakter sehingga mulai tahun 2014 pemerintah mewajibkan seluruh sekolah di Indonesia untuk memberikan pendidikan karakter bagi peserta didik. Kondisi Pendidikan karakter dilatarbelakangi oleh keinginan untuk mewujudkan konsensus nasional yang mengacu kepada Pancasila dan UUD 1945. Konsensus tersebut berikutnya diperluas melalui suatu UU No. 20 tahun 2003 tentang Sistem Pendidikan Nasional yang menyatakan: "Pendidikan nasional berfungsi mengembangkan kemampuan dan membentuk watak serta peradaban bangsa yang bermartabat dalam rangka mencerdaskan kehidupan bangsa, bertujuan untuk berkembangnya potensi peserta didik agar menjadi manusia yang beriman dan bertakwa kepada Tuhan Yang Maha Esa, berakhlak mulia, sehat, berilmu, cakap, kreatif, mandiri, dan menjadi warga negara yang demokrasi serta bertanggung jawab". Dalam pasal tersebut terlihat bahwa perilaku yang daharapkan berkorelasi dengan tujuan pendidikan. Keterlekatan yang ada pada pendidikan karakter inilah yang menjadi land hukumasan pentingnya pendidikan karakter.

Terlebih bahwa pembinaan karakter santri sebagai seorang pelajar remaja dihadapkan pada beberapa fenomena, di antaranya: Pertama, santri berada pada usia transisi antara masa kanak-kanak dan dewasa, dimana terjadi pertumbuhan yang sangat cepat (growth spurt) yang menimbulkan perubahan secara psikologi dan kognitif. Santri di satu sisi memang kerap menampilkan sisisisi kanak-kanaknya, namun di sisi lain dituntut untuk cepat menjadi dewasa. Usia santri biasanya 
secara psikologi membutuhkan identitas diri (self identity). Pada masa ini mereka membutuhkan berbagai informasi untuk memenuhi kognisi dan penyempurnaan kepribadiannya. Kedua, sebagai bagian dari lapisan struktur masyarakat, santri memiliki karakteristik yang cukup unik yang cenderung memiliki berbagai persepsi terhadap adanya perubahan.

Pengembangan karakter santri memiliki model yang berragam sesuai dengan corak pesantrennya. Dalam Direktori Pesantren seIndonesia terbitan tahun 2007, pesantren dibagi ke dalam tiga corak atau tipologi dari seluruh pondok pesantren yang ada di wilayah nusantara yang diperkirakan berjumlah 14.656. Pertama, pesantren yang memiliki corak tradisional (salafy) mencapai 9087 pesantren atau $62 \%$. Pesantren yang bercorak tradisional pada umumnya adalah pesantren yang telah lama eksis dan masih tetap mempertahankan corak tradisionalnya. Kedua, pesantren yang memiliki corak modern (khalafy), jumlahnya mencapai 1172 pesantren atau 8\% dari jumlah keseluruhan pesantren di negeri ini. Ketiga, corak terpadu atau kombinasi (mutawasith) dengan sistem sekolah jumlahnya mencapai 30 \% (4397 pesantren) dari pesantren yang ada. Maka melalui optimalisasi pengembangan karakter diharapkan setiap santri mendapatkan pengembangan karakter keagamaan dan kebangsaan agar mereka memiliki pengetahuan (knowledge), sikap (attitude), dan prilaku (behavior) sehingga menjadi peserta didik yang selaras dengan tujuan pendidikan (Muslich, 2011: 29).

Penelitian ini dioriantasikan untuk menjawab persoalan pola pengembangan karakter santri dan wujud kultur yang diimplementasikan di pesantren Persis Tasikmalaya Jawa Barat. Melalui persoalan tersebut, maka tujuan penelitiannya adalah mengetahui pola pengembangan karakter santri dan wujud kultur yang diimplementasikan di pesantren Persis Tasikmalaya Jawa Barat.

Signifikansi dan manfaat penelitian ini memperkaya pengetahuan dalam pembentukan karakter di kalangan santri melalui kultur di pesantren. Secara praktis pnelitian ini dapat dijadkan pijakan bagi pihak pesantren dalam menerapkan pola pembentukan karakter santri.

\section{Tinjauan Pustaka}

Karakter merupakan moral excellence atau akhlak yang dibangun atas berbagai kebajikan(virtues). Karakter baru memiliki makna jika dilandasi nilai-nilai kebudayaan. Jadi, karakter bangsa adalah karakter warga negara yang dinilai sebagai kebajikan. Karena itu, national and character building harus berorientasi pada upaya pengembangan nilai-nilai kebajikan sehingga menghasilkan output yang memiliki jati diri dan kepribadian. Sementara menurut Lickona, karakter merupakan "A reliable inner disposition to respond to situations in amorally good way.Character so conceived hasthree interrelated parts: moral knowing, moral feeling, and moral behavior" (Lickona, 1992). Lickona menambahkan bahwa karakter mulia (good character) menyangkut pengetahuan tentang kebaikan yang menimbulkan komitmen terhadap kebaikan yang akhirnya benar-benar kebaikan tersebut dilakukan oleh pelakunya. Karakter mengacu kepada serangkaian pengetahuan, sikap, motivasi, perilaku, dan keterampilan.

Dalam perspektif Islam, karakter identik dengan akhlak sehingga karakter merupakan nilai-nilai prilaku manusia yang bersifat universal. Terdapat beberapa konsep dalam pendidikan Islam yang merupakan pendidikan yang mengembangkan karakter anak didik. Pendidikan akhlak adalah pendidikan yang dimaksudkan sebagai bentuk pendidikan untuk mengembangkan sikap, watak, dan karakter anak didik (Hasanah, 2012).

Terminologi pendidikan karakter mulai dipromosikan sejak tahun 1990-an oleh Thomas Lickona ketika menulis buku yang berjudul The Return of Character Education dan Educating for Character: How our school Can teach Respect and responsibility. Melalui buku tersebut, Lickona menyadarkan Dunia Barat akan pentingnya pendidikan karakter. Sementara pencetus pendidikan karakter yang menekankan etis-spiritual pada pembentukan pribadi adalah pedagogik adalah Jerman FW Forester (Muslich, 2011: 37). Bagi Forester karakter menjadi pembeda pribadi seseorang (identity). Pendidikan memiliki misi yang sama dengan pendidikan akhlak dan pendidikan moral. Secara konseptual kata akhlak dan moral mempunyai makna yang serupa yaitu sama-sama membincangkan perbuatan dan perilaku manusia ditinjau dari sudut pandang nilai baik dan buruk. Namun pada aspek implementasi akhlak lebih pada tataran filosofis sebagai acuan untuk mengkaji sistem nilai, seperti yang dikemukakan oleh alGhazali (Djatnika, 1996:27). Bahwa perangai adalah suatu sifat yang tetap pada suatu jiwa yang menimbulkan perbuatan-perbuatan dengan mudah dan tidak membutuhkan kepada pikiran, sedangkan 
moral adalah perasaan terhadap perbuatan itu baik atau buruk.

Terdapat beberapa komponen pendidikan karakter, antara lain: Pertama, pengajaran. Pengajaran sering disebut dengan pembelajaran. Majid (2011), menyatakan bahwa pembelajaran adalah upaya untuk membelajaarkan seseorang melihat berbagai upaya, strategi metode, dan pendekatan ke arah pencapaian tujuan yang telah direncankan). Kedua, peneladanan. Peneladanan merupakan metode yang ditunjukkan dalam perilaku dan sikap pendidik. Ketiga, pembiasan. Pembiasaan merupakan sesuatu yang dibiasakan, dilakukan, diamalkan. Menurut para ahli, metode ini sangat efektif untuk pembinaan karakter dan kepribadian anak. Orang tua membiasakan anakanaknya untuk menyikat gigi, maka menyikat gigi bagi anak itu akan menjadi kebiasaan. Metode pembiasaan ini sangat praktis dalam pembinaan dan pembentukan karakter anak usia dini untuk meningkatkan pembiasaan-pembiasaan pelaksanaan kegiatan disekolah.

Hakekat pembiasaan sejatinya merupakan kegiatan yang dialami atau pengalaman itu sendiri. Pembiasaan merupakan kegiatan yang dilakukan. Metode pembiasaan biasanya memiliki efektifitas dalam pembinaan sikap sebab dapat melatih tindaan yang baik kepada anak sedini mungkin. Pembiasaan juga menjadi model penanaman kecakapan berbuat dan berinteraksi. Model ini juga dilaakukan agar anak merasa bahwa apa yang dilakukannya tidak membuatnya menjadi bosen dan menjenuhkan.

Pembiasaan dalam pendidikan karakter merupakan aspek yang sangat penting sebagai bagian dari proses pembentukan sikap dan prilaku yang relatif menetap dan bersifat otomatis melalui proses pembelajaran yang berulang-ulang (Hasanah, 2012: 137). Pembiasaan merupakan perbuatan sengaja yang dilakukan secara berulang-ulang, sehingga menjadi pengalaman yang diamalkan. Oleh karena itu yang menjadi kunci dalam pembiasaan adalah pengalaman. Rasulullah mengajarkan agar para orang tua "selaku pendidik" mengajarkan shalat kepada anak-anak dalam usia tujuh tahun, "suruhlah anak-anak kalian melaksanakanm shalat dalam usia tujuh tahun, dan pukullah mereka apabila meninggalkannya ketika meraka berumur sepuluh tahun, dan pisahkannlah tempat tidur mereka" (HR. Abu Dawud). Membiasakan anakanak melaksanankan sholat secara berjamaah itu penting, karena dengan kebiasaan ini akan membangun karakter yang melekat dalam diri mereka.
Keempat, pemotivasian. Istilah pemotivasian berasal dari kata dasar "motivasi" yang mendapat awalan "pe" dan akhiran "an". Secara etimologi, kata motivasi menurut para ahli berasal dari bahasa latin movere (menggerakan). Ada juga yang mengatakan bahwa motivasi berasal dari bahasa inggris motivation yang berarti to move/to drive (menggerakkan/mendorong) (Gintings, 2010: 86). Motivasi merupakan faktor yang mempunyai arti penting bagi siswa sehingga tidak ada artinya jika siswa belajar tanpa adanya motivasi (Hasanah, 2012: 37). Kelima, penegakkan aturan. Penegakkan aturan merupakan setting limit dimana ada batasan yang tegas dan jelas mana yang harus dan mana yang tidak harus dijalankan (Hasanah, 2012: 13).

Secara implementatif, penegakan aturan diterapkan mulai dari tahap perencanaan, tahap pelaksanaan, dan berikutnya tahap evaluasi. Pada tahap perencanaan dikembangkan perangkat karakter yang digali, dikristalisasikan, dan dirumuskan dengan menggunakan berbagai sumber, antara lain pertimbangan atau filosofis Pancasila, Undang Undang Dasar dan UndangUndang Nomor 20 tahun 2003.

Dengan demikian, maka pendidikan karakter dapat dilakukan di pesantren. Team Penulis Departemen Agama (2003: 3) dalam buku Pola Pembelajaran Pesantren mendefinisikan bahwa pondok pesantren adalahpendidikan dan pengajaran Islam di mana di dalamnya terjadi interaksi antara kiai dan ustdaz sebagai guru dan para santri sebagai murid dengan mengambil tempat di masjid atau di halaman-halaman asrama (pondok) untuk mengkaji dan membahas bukubuku teks keagamaan karya ulama masa lalu. Dengan demikian, unsur terpenting bagi pesantren adalah adanya kiai, para santri, masjid, tempat tinggal (pondok) serta buku-buku (kitab kuning).

Pesantren merupakan lembaga pendidikan Islam tradisional yang mempelajari ilmu agama (tafaqquh fi al-dîn) dengan penekanan pada pembentukan moral santri agar bisa mengamalkannya dengan bimbingan kiai dan menjadikan kitab kuning sebagai sumber primer serta masjid sebagai pusat kegiatan. Dhofier (1985) mengungkapkan bahwa lembaga pendidikan pesantren memiliki beberapa elemen dasar yang merupakan ciri khas dari pesantren itu sendiri. Setidaknya terdapat lima unsur pokok pesantren, yaitu: Ajengan/Kiyai,Santri, Masjid, Pondok, dan Kitab Kuning (Kitab Klasik). 


\section{METODE PENELITIAN}

Penelitian ini menggunakan pendekatan kualitatif. Melalui pendekatan ini, penelitian diarahkan untuk mendapatkan data secara deskriptif yang memadai dari permasalahan penelitian ini.

Penelitian dilakukan di Pesantren Persis Benda Tasikmalaya dengan menerapkan tiga model penggalian data, antara lain: Pertama, observasi. Kedua, wawancara mendalam (indepth nterview), dan metode focus group discussion.

Jenis data dikumpulkan dalam penelitian ini adalah perkataan dan tindakan (strategi) yang dilakukan oleh santri dan ustadz. Sumber data utama dalam penelitian kualitatif adalah kata-kata dan tindakan, selebihnya merupakan tambahan seperti dokumen dan sebagainya. Lebih lanjut dalam penelitian kualitatif jumlah sampel bukan merupakan ukuran utama, tetapi lebih ditekankan pada sumber data yang memberikan informasi yang sesuai dengan tujuan penelitian. Adapun langkah untuk menggali informasi dari berbagai sumber data, dilakukan dalam situasi yang wajar.

Informan yang dipilih dalam penelitian ini terdiri dari beberapa orang yang dianggap menguasai informasi sehubungan dengan masalah yang akan dikaji, yaitu antara lain: Pertama, sebagai key informan (pengasuh pesantren, para ustazd, para santri). Kedua, sebagai informan lanjutan/pelengkap (masyarakat sekitar, orang tua santri, komite, dan aparatur pemerintahan setempat.

\section{PEMBAHASAN}

\section{Model Pengembangan Karakter}

Pesantren Persatuan Islam (PERSIS) 67 Benda adalah sebuah Pesantren yang berada di Kabupaten Tasikmalaya Jawa Barat. Tasikmalaya sendiri terkenal dengan sebutan Kota Santri, sebab di Kota ini terdapat banyak pesantren yang menjadi basis pendidikan kaum santri dan pangkal pusat Dakwah Islamiyah. Pesantren Persatuan Islam (PERSIS) 67 Benda sebagai salah satu pesantren besar di wilayah Kota Tasikmalaya cukup populer di kalangan umat Islam di Jawa Barat. berada di sebelah utara Kota Tasikmalaya tepatnya di Kampung Benda Kelurahan Nagarasari Kecamatan Cisalak Kabupaten Tasikmalaya. Pesantren ini menempati areal seluas kurang lebih 3,5 Hektare.

Berdirinya Pesantren ini awalnya merupakan sebuah Majlis Ta'lim (Pengajian Agama Islam) yang diadakan oleh $\mathrm{KH}$. Usman Aminullah yang sering dipanggil dengan panggilan Ustad Amien oleh semua kalangan umat. Majlis Ta'lim ini berupa pengajian di rumah orang tua Ustad Amien yang dilaksanakan setelah magrib saja. Tetapi dikarenakan jumlah anak yang ikut mengaji semakin hari semakin bertambah banyak, mau tidak mau pengajian dipindahkan ke sebuah tempat yang berukuran kurang lebih 5 × 6 meter. Tidak terasa ternyata semakin kesini jumlah santri yang ada dipengajian majlis ta'lim ini semakin bertambah banyak, bahkan ada juga santri yang datang jauh jauh hanya untuk mengaji, maka oleh Ust. Amien didirikanlah sebuah Madrasah yang berukuran 7 x 40 meter. Pengajian pun diubah jadwalnyadari maghrib menjadi pagi hari. Pada tanggal 4 Mei 1940 diresmikanlah Madrasah tersebut sebagai Pesantren Persatuan Islam No. 67 Benda oleh Pimpinan Pusat Persatuan Islam yang pada saat itu sedang diketuai oleh KH. Isa Ashari.

Pesantren Persis 67 Benda sedikit demi sedikit berkembang dengan diawali berdirinya sebuah madrasah Diniyyah, ibtidaiyyah dan Tsanawiyyah. Sehingga pada tahun 1976, Ustadz Amin menyerahkan kepengurusan Pesantren Benda ini kepada Putranya sendiri bernama Drs. H. Shiddiq Amien, MBA. Beberapa tahun Kemudian Pesantren ini Berkembang bahkan maju seperti yang kita sudah lihat sekarang. Sepeninggal Ust. Shiddiq Amien pada 31 Oktober 2009 memberikan sebuah kesedihan yang sangat mendalam bagi para keluarga besarpesantren benda ini. sehingga pada akhirnya kepimpinan pesantren dilanjutkan oleh kakak beliau sendiri yang kita kenal namanya K.H. Muhtarom Amien yang akan mewujudkan visi pesantren benda ini kedepannya dengan cara terus mengamalkan ajaran islam dengan baik dan benar sesuai dengan Al-Qur'an dan As Sunnah.

Pesantren Persis 67 Benda memiliki visi "Menjadi sebuah Pesantren terdepan dalam membentuk Insan Ulul Albab dan Tafaquh Fiddien, menjadi Waladan Sholihan serta kader Ulama dan Zu'ama masa depan. Sedangkan misinya antara lain:(1) Mempertebal keimanan dan ketaqwaan (2) Membina Akhlakul Karimah (3) Memahami dan mengamalkan ajaran Islam dengan baik dan benar sesuai dengan al-Qur'an dan As-Sunnah (4) Menguasai Ilmu pengetahuan dan teknologi (5) Mengembangkan minat dan bakat. Tujuan yang hendak dicapai pesantren ini adalah: (1) Lulusan Pesantren Persatuan Islam 67 Benda ditargetkan dan diharapkan menjadi Insan Muslim yang (2) Berakidah lurus dan bersih dari: Syirik, Riya, Hasud, Syukuk dan sebagainya (3) Beribadah dengan baik dan benar (4) Berakhlakul Karimah (5) Berilmu 
dan berwawasan luas (6) Berbadan sehat dan kuat (7) Hidup terampil dan mandiri (8) Siap menjadi guru dan da'i (9) Bermanfaat bagi keluarga dan masyarakat.

Pesantren 67 Benda ini berada dinaungan Persatuan Islam yang merupakan institusi komunitas muslim yang berdiri dengan diilhami oleh firman Allah SWT, surat Ali-Imran ayat 103, "wa'tasimuu bihablillahi jamii'a(n) 'wa laa tafarraqu", yang artinya berpegang teguhlah kepada tali Allah dan jangalah bercerai-berai. Serta hadist riwayat Ibnu Mas'ud yang bebunyi, "man kana 'ala al-haq fawuha jama'ah walau kana wahdah". Firman Allah yang menganjurkan berpegang teguh pada tali agama Allah, artinya jangan berpecah belah.

Persatuan Islam berdiri pada tahun 1920an, tepatnya pada tanggal 12 september $1923 \mathrm{di}$ Bandung. Idenya bermula dari seorang alumnus Dar al-Ulum Mekkah bernama H. Zamzam yang sejak tahun 1910-1912 menjadi guru agama di sekolah agama Darul Muta'alimin dan pemberian nama "Persatuan Islam" itu sendiri mempunyai pengertian sebagai "Persatuan Pemikiran Islam, Persatuan Rasa Islam, Persatuan Usaha Islam, dan Persatuan Suara Islam".

Sejalan dengan pengembangan karakter santri, Pesantren Persatuan Islam (PERSIS) 67 Benda menerapkan sistem sekolah merangkap pesantren, yakni santri yang sekolah itu wajib di pesantren (diasramakan). Model sekolah merangkap ini sebenarnya sudah melebihi programfull day school karena waktu pulang sekolah di progam full day school hanya sampai waktu Ashar, sementara realisasi dari sekolah merangkap adalah sehari penuh dan istirahat hanya sekedar makan dan shalat berjamaah. Shalat berjamaah memiliki makna penting bagi pesantren yang berada di bawah Persatuan Islam.Para santri menegaskani bahwa berjama'ah adalah berpegang teguh pada kebenaran walaupun ketika sedang sendirian. Al-Qur'an dan As-Sunnah memberikan perintah bahwa persatuan dapat diwujudkan dengan membentuk jama'ah. Berjama'ah adalah langkah menuju terbentukya jami'iyyah yang potensial mewujudkan persatuan. Jami'iyyah Persatuan Islam terbentuk dari tiga unsur prinsipil, yakni hidup berjama'ah, berimamah, dan berimarah. Ber-jamaah, artinya berkumpul dalam suatu wadah tertentu, diartikan pula bersama-sama melaksanakan kegiatan, atau dapat pula diartikan memiliki prinsip yang sama, sumber ajaran yang sama, dan tolak ukur yang sama dalam mengerjakan sesuatu, menilai sesuatu, dan mengembagkan segala hal yang berkaitan dengan kehidupan beragama, kehidupan sosial, dan kebudayaan. Sedangkan imamah dan imarah adalah al-haq atau kebenaran.

Prinsip utama ber-jama'ah bagi anggota organisasi masyarakat Islam Persatuan Islam adalah membentuk perilaku kolektif, yakni perilaku yang secara homogen mencirikan anggota Persatuan Islam memiliki prinsip yang sama dalam berperilaku. Denga demikian, semua anggota secara kolektif berperilaku dengan berpegang teguh pada Al-Qur'an dan As-Sunnah. Dalil yang dijadikan argumentasi oleh anggota Persatuan Islam adalah sebuah hadist yang menegaskan bahwa Rasulullah Saw meninggalkan dua hal penting bagi umatnya, bila berpegang pada keduanya maka akan selamat, sedangkan bila keluar dari dua hal itu akan celaka. Kedua hal tersebut adalah Al-Qur'an dan AsSunnah. Segala sesuatu atau tindakan dalam beragama atau melakukan sebuah ritus, seorang anggota Persatuan Islam harus senantiasa ada dalil yang bisa dijadikan pegangan dalam bertindak.

Dari segi pemahaman, organisasi masyaakat Islam ini sudah sejak awal bersifat liberal. Betapa tidak, nama Persatuan Islam yang disingkat PERSIS adalah nama latin, yang dianggap sebagai pengaruh penjajahan Belanda. Apalagi jika menyangkut denga sesuatu yang disakralkan dan diidentikan dengan ajaran agama. Dari segi ini, Persatuan Islam menghendaki apa yang seharusnya disakralkan dan apa yang tidak seharusnya disakralkan oleh umat Islam. Kemudian, Persatan Islam menjadi sebuah organisasi yang paling ekstri dan liberal dalam melakukan pertentangan terhadap tradisi-tradisi yang dianggap bid'ah, khurafat dan tahayul.

Persatuan Islam memang memiliki ciri khas atau karakteristik dalam membentuk karakter perilaku beragama para anggotanya, yaitu: Pertama, mengamalkan ajaran Islam menurut tuntunan Al-Qur'an dan As-Sunnah. Kedua, menjadi thaifatun Mutafaihuna fi'dien (sekelompok orang memperdalam agama) atau ulama. Ketiga, menempatkan dirinya pada aqidah dan syariah Islam menurut tuntunan Al-Qur'an dan As-Sunnah. Keempat, para anggota jamiyyah Persatuan Islam, khususnya dan umat Islam Indonesia umumnya dapat ikut serta secara aktif dalam mewujudkan masyarakat yang diridhai Allah SWT. Kelima, menjadi hamba Allah SWT yang bertaqwa kepadaNya.

Adapun dalam lingkungan umat, ustadz dalam organisasi masyarakat Persatuan Islam 
berperan membangun solidaritas dan hubungan sosial yang maslahat dengan jalan membina tatanan masyarakat muslim dengan cara sebagai berikut: (1) melaksanakan aktivitas dakwah melalui berbagai cara dan media yang ma'ruf (2) membela dan menyelamatkan umat Islam dari gangguan musuh-musuh Islam dengan cara haq dan ma'ruf (3) menghidupkan dan memelihara ruhul jihad dan ijtihad (4) membasmi bid'ah, tahayul, taqlid, syirik dan munkarat lainnya.

Melihat dari pemahaman, sikap, dan prilaku santri, maka pengembangan karakter dapatdilihat pada pada 3 (tiga) aspek, yakni: pengajaran, pembiasaan, dan penegakan aturan.

\section{Pengajaran}

Pada aspek pengajaran, salah satu komponen yang diperhatikan adalah kurikulum. Kurikulum merupakan perpaduan antara kurikulum khas Pesantren yang digabungkan dengan kurikulum sekolah pemerintah (Departemen Pendidikkan Nasional dan Departemen Agama). Santri yang tinggal di asrama memperoleh tambahan berupa ngaji, latihan pidato, ngaji Alquran setiap subuh, belajar mandiri dan belajar kelompok setiap sore dan malam hari, serta aktifitas ibadah dan sosial lainnya.

Adapun prinsip-prinsip yang diperhatikan para ustadz dalam pengembangan kurikulum, yaitu: Pertama, prinsip relevansi. Prinsip relevansi adalah kedekatan hubungan antara materi pembelajaran dan fenomena yang teradi sehingga hasil pendidikan yang diperoleh akan berguna bagi kehidupan santri di masyarakat. Kedua, prinsip fleksibilitas. Kurikulum yang dikembangkan harus memilki ruang gerak yang memberikan kebebasan dalam bertindak, memilih program pendidikan, dan fleksibilitas dalam pengembangan program pembelajaran. Ketiga, prinsip efisiensi. Prinsip efisiensi terkait dengan usaha, biaya, waktu, dan tenaga yang digunakan dalam proses pembelajaran. Keempat, prinsip efektivitas. Prinsip ini untuk melihat sejauh mana perencanaan kurikulum dapat dicapai sesuai dengan keinginan yang telah ditentukan. Efektivitas kurikulum berkaitan dengan proses mengajar bagi ustadz, dan proses belajar bagi santri. Kelima, prinsip kesinambungan. Prinsip kesinambungan dalam pengembangan kurikulum menunjukkan adanya keterkaitan antara tingkat pendidikan, jenis pendidikan, program pendidikan dan bidang studi antara lain: (1) kesinambungan di antara berbagai tingkat pendidikan (diniyah, tsanawiyah dan muallimin) yang menyangkut bahan ajar yang diperlukan untuk belajar lebih lanjut pada tingkat pendidikan yang lebih tinggi sudah diajarkan pada tingkat pendidikan sebelumnya, dan bahan pelajaran yang sudah diajarkan pada tingkat yang lebih rendah tidak diajarkan lagi pada tingkat yang lebih tinggi, sehingga tidak terjadi tumpang tindih bahan pelajaran (2) kesinambungan di antara berbagai bidang studi yang berkaitan dengan hubungan antara bidang studi yang satu dengan yang lain. Keenam, prinsip berorientasi tujuan. Bahwa langkah awal sebelum memilih dan mengembangkan komponen-komponen kurikulum ialah menetapkan tujuan. Kemudian komponen kurikulum lainnya dipilih dan dikembangkan dalam rangka mencapai tujuan tersebut.

Nilai-nilai karakter yang diajarkan melalui materi dan pembelajaran, tidak hanya sekadar dipelajari oleh santri sebagai ilmu pengetahuan saja. Nilai-nilai karakter tersebut oleh santri diaplikasikan atau dipraktikkan dalam kehidupan sehari-harinya, baik ketika di dalam pondok pesantren ataupun ketika kembali ke lingkungan keluarga. Disamping itu, untuk meningkatkan dan mempertahankan nilai-nilai karakter pada santri tersebut pondok pesantren melakukan berbagai upaya. Salah satunya adalah menetapkan peraturan yang mewajibkan santri untuk mengikuti setiap kegiatan yang diselenggarakan pondok pesantren. Hal tersebut dimaksudkan sebagai pembiasaan atau keteladanan agar nantinya santri dengan sendirinya akan melaksanakan kegiatan-kegiatan tersebut dengan senang hati dan suka rela tanpa merasa dibebani dengan adanya kewajiban-kewajiban tersebut.

Penggunaan metode pembelajaran yang tepat memang sangat dibutuhkan dalam proses pendidikan karakter. Terlebih lagi penggunaan metode yang disesuaikan dengan taraf kemampuan pembelajaran santri.

Hal tersebut perlu diperhatikan mengingat bahwa keberhasilan pendidikan karakter di pondok pesantren juga bergantung pada metode pendidikan yang digunakan.Oleh karenaitu, guna meningkatkan keberhasilan pelaksanaan pendidikan karakter, pondok pesantren menerapkan metode konfirmasi sebagai wujud evaluasi dalam keseharian para santri.

Adapun nilai-nilai karakter yang masuk pada materi antara lain: Taat asas, amal shaleh, nasionalisme atau cinta tanah air, semangat 
kebangsaan, jujur/shidiq, kerja keras, disiplin, demokrasi, peduli lingkungan, peduli sosial, religious, sabar, ikhlas, cinta kasih, tanggung jawab, rela berkorban, tablig, amanah, fathanan. Cinta ilmu, keberanian, adil, rajin dan kreatif. Selain itu terdapat karakter bersahabat/solidarity, komunikatif, istiqamah, berpikir jauh ke depan, menepati janji, kasih sayang, kerjasama, mandiri dan. Sementara nilai-nilai yang termuat dalam desain rencana merupakan upaya penguatan nilai-nilai karakter tertentu yang sekiranya dapat dilaksanakan oleh ustazd pengampu secara masimal.

Kegiatan evaluasi yang dilaksanakan oleh Pesantren Persis 67 Benda dilakukan sebagai pemetaan kekuatan antisipasi kemungkinan penurunan kualitas dan kuantitas santri, untuk peningkatan profesionalisme manajemen perpesantrenan, sebagai alat regulasi diri (selfregulation) pesantren, mengukur mutu hasil pendidikan, mengetahuikemajuan dan kemunduran pesantren, membuat keputusan kepada santri serta mengadakan perbaikan kurikulum dengan memakai model pendekatan proses pada sistem pendidikan tersebut.

Faktor pendukung evaluasi terpadu ada dua faktor yakni faktor internal atau dari diri peserta yang ingin saling belajar, dan saling berbagi pengalaman sedangkan faktor eksternal adalah adanya materi yang selalu up to date atau yang aktual; dan upaya pemberdayaannya yang dilakukan berupa sosialisasi materi hasil evaluasi terpadu. Sedangkan faktor penghambatnya adalah dari sumber daya manusianya (SDM) sedangkan faktor eksternalnya adalah waktu dan teknis pelaksanaannya. Keefektifannya tercermin pada tertatanya program kerja pesantren, kerja sama, kinerja dan kedisiplinan ustadz, kualitas lembaga (prestasi) baik akademik maupun non akademik, output (keluaran) cukup bagus dibanding dengan input (masukan). Semua hal ini bermuara pada suatu titik harapan yakni menghasilkan output pendidikan yang berkualitas (bermutu).

\section{Pembiasaan}

Karakter harus diterapkan melalui suatu pembiasaan, tidak cukup hanya diajarkan melalui mata pelajaran di kelas saja. Kegiatan pembiasaan secara spontan dapat dilakukan misalnya saling menyapa, baik antar teman, antar ustadz maupun antar ustadz dan santri. Pembiasaan diarahkan pada upaya pembudayaan suatu aktivitas sehingga aktivitas tersebut menjadi aktivitas yang terpola atau tersistematis.

Aspek pembiasaan menjadi perhatian utama di Pondok Pesantren Persis. Pembiasaan diterapkan melalui penanaman nilai. Penanaman nilai karakter religius dapat terlihat dalam berbagai kegiatan santri, baik yang bersifat formal maupun non formal. Selain penanaman nilai religius, pondok pesantren juga mengajarkan nilai kemandirian dan nilai tanggung jawab. Nilai-nilai tersebut dapat terlihat dalam berbagai macam kegiatan, pembiasaan serta kurikulum yang diterapkan di pondok pesantren. Nilai kemandirian mengajarkan santri bahwa setiap manusia disamping sebagai makhluk sosial yang saling membutuhkan satu sama lain, ia juga harus dapat memenuhi kebutuhannya sendiri. Santri diajarkan kemandirian agar dapat mengetahui seberapa jauh kemampuan dirinya dan dapat mengembangkan potensinya selama berada di pondok pesantren. Kegiatan yang dapat dijadikan sebagai wadah penanaman nilai kemandirian adalah sekolah formal, menyiapkan makan dan dalam hal memilih ekstrakurikuler. Sedangkan pembiasaan yang dapat dijadikan sarana penanaman nilai kemandirian seperti mempersiapkan kebutuhan sekolah serta membersihkan kamar setiap hari. Selain nilai kemandirian adapula nilai-nilai karakter lain yang juga diunggulkan oleh pondok pesantren yaitu nilai tanggung jawab.

Pada dasarnya nilai tanggung jawab yang diajarkan dapat terlihat dalam setiap kegiatan keseharian para santri. Hal ini dikarenakan karena setiap kegiatan yang ditetapkan oleh pesantren wajib dilaksanakan oleh seluruh santrinya. Dengan adanya kewajiban tersebut, para santri dituntut untuk dapat bertanggung jawab dalam menjalankan setiap kegiatan dan dapat menerima segala sanksi atas segala sikap dan perilakunya selama menjalankan kegiatan tersebut.

Penanaman nilai tanggung jawab tidak hanya mengajarkan santri untuk mampu bertanggung jawab pada dirinya sendiri akan tetapi juga tanggung jawab pada orang lain. Beberapa contoh kegiatan yang dapat menanamkan nilai tanggung jawab tersebut antara lain kewajiban sholat berjamaah, hafalan Alquran, membersihkan asrama, olahraga dan pemilihan murabbi. Seperti yang dijabarkan dalam tabel berikut ini :

Penanaman nilai-nilai karakter dalam setiap kegiatan santri di pondok pesantren memiliki banyak manfaat tidak hanya saat santri belajar di pondok pesantren, tetapi juga saat mereka hidup bermasyarakat. Biasanya akan terlihat perbedaan 
sikap dan perilaku santri ketika sebelum dan sesudah masuk pondok pesantren. Santri yang semula masih berperilaku buruk, setelah beberapa bulan mengikuti kegiatan dan pembiasaan di pondok pesantren hidupnya menjadi lebih terarah dan lebih rajin beribadah kepada Tuhan. Hal tersebut juga didukung dengan adanya peraturan yang mewajibkan setiap santri untuk mengikuti setiap kegiatan di pondok pesantren baik dalam hal berjamaah, mengaji, ataupun kegiatan lainnya. Bagi santri yang tidak mengikuti kegiatan tanpa izin ataupun melanggar peraturan akan dikenakan sanksi yang sesuai dengan pelanggaran yang ia lakukan.

Bagi santri, belajar bukan saja memahami yang boleh dilakukan dan apa yang tidak boleh dilakukan (halal dan haram), tetapi mereka belajar adanya pilihan nilai yang sesuai dengan perkembangan. Santri dapat memaksimalkan diri untuk berpikir strategi agar dapat mengamalkan nilai-nilai keagamaan, membiasakan berdo'a sebelum dan sesudah mengikuti mata pelajaran, ikut aktif dalam kegiatan kerohanian atau siraman rohani, taat dan rajin beribadah, shalat berjama'ah bersama di pesantren. Santri membiasakan diriberprilaku jujur dalam menggunakan uang saku, jujur mengerjakan tugas dan ulangan, jujur mengembalikan barang milik orang lain, meminta maaf jika salah kepada orang lain, jujur dalam pertandingan olahraga.

Santri juga dibiasakan untuk disiplin. Disiplin diekspresikan dengan disiplin pulang ke pondok tepat waktu, disiplin membayarkan uang pesantren, disiplin mentaati peraturan pesantren, disiplin dalam mengumpulkan tugas pesantren, disiplin antri di kantin, dan kamar mandi. Santri juga dibiasakan untuk santun yang diekspresikan dengan santun dalam berbicara dengan orang tua dan ustadz, santun dalam berjalan di depan orang tua dan ustadz, santun ketika berangkat ke pesantren, santun masuk dan keluar kelas. Santri juga dibiasakan untuk tangguh. Sikap tangguh diekspresikan dalam ketangguhan dalam menolong orang yang sakit, tangguh dalam melindungi diri sendiri, tangguh dalam menjaga alam.

Toleransi dengan menghargai teman yang sedang beribadah, Menghargai pendapat orang lain. Demokratis dengan berpartisi pasi dalam pemilihan ketua OSIS, Berpartisipasi dalam pemilihan ketua kelas, Pemilihan ketua Karang Taruna di desa. Nasionalisme dengan Mengikuti upacara rutin setiap Senin, Menjaga foto para pahlawan di kelas, Mendengarkan lagu perjuangan.
Peduli sosial dan solidaritas dilaksanakan dengan bakti sosial, menjenguk dan membantu teman yang sakit, mengunjungi keluarga teman yang terkena musibah, Membantu orang tua yang akan menyebrang jalan. Tanggung jawab dilaksanakan dalam membayar kas kelas, Tanggung jawab dalam kebersihan piket kelas, Tanggung jawab dalam mengerjakan tugas kelompok, Tanggung jawab dalam pekerjaan rumah.

Santri mualimin dalam pembelajarannya diwajibkan menghapal beberapa juz (minimal $5 \mathrm{Juz}$ ) yang telah diperintahkan oleh ustazd-nya. Setiap hari santri diwajibkan membaca Alquran sebelum belajar. Selain menghafal, setiap santri harus bisa memahami apa yang diajarkan oleh Ustazd, seperti penerapan ahlak-ahlak yang mulia, budi pekerti, jujur, sopan santun, cinta Tuhan dan orang tua, dan lain-lain. Upaya pembiasaan ini agarsantri memiliki rasa tanggung jawab, baik dan rendah hati, toleransi, perdamaian.

Selain itu, santri juga dikenalkan dengan lingkungan sosial melalui praktik-praktik lapangan. Dengan metode pengenalan lingkungan tersebut, maka diharapkan dapat membantu santri untuk lebih mengenal dunia luar dengan menilai estetika, etika dan segala macam hal yang ada di masyarakat. Sosialisasi masyarakat memberikan berbagai pelajaran dan pengalaman bagi seorang santri. Santri dapat belajar segala hal dari orangorang yang ditemuinya ketika bersosialisasi dengan masyarakat.

\section{Penegakkan Aturan}

Proses penegakkan aturan atau hukum diterapak sistem larangan, sanksi, dan penghargaan prestasi santri. Sistem-sitem tersebut dilakukan oleh Mudir, Ustadz, Murabbi (Komponen Pesantren). Proses penegakkan hukum memiliki paradigma merubah paradigma kekerasan menjadi model motivasi. Bentuknya berupa menciptakan ketertiban dan keamanan lingkungan. Sanksi yang diberikan sebagai model motivasional dalam penegakkan hukumnya adalah muhafadoh, membersihkan lingkungan pesantren, menegakkan kedisiplinan, dan ketaatan.

Pihak pesantren menerapkan beberapa peraturan antara lain: Santri tidak diizinkan untuk membawa telepon genggam ke dalam pondok pesantren dan memainkan sosial media seperti facebook dan lain sebagainya. Dengan adanya peraturan tersebut diharapkan pendidikan karakter dapat berjalan dengan maksimal dan karakter santri 
yang telah dibangun di dalam pondok pesantren tidak cepat terpengaruh oleh pergaulan luar yang terkadang membawa pengaruh buruk dalam diri santri. Hal tersebut juga didukung oleh wali santri yang menginginkan karakter anak-anak mereka menjadi lebih baik. Dalam hal ini selain pengurus pondok pesantren, wali santri juga ikut terlibat dalam pelaksanaan pendidikan karakter. Wali santri tidak secara langsung lepas tangan setelah memasukkan anak-anak mereka kedalam pondok pesantren, akan tetapi mereka tetap mengawasi pelaksanaan pendidikan karakter pada anak-anak mereka.

Selain itu untuk menghindari kebiasaankebiasaan buruk yang dibawa oleh santri dari lingkungan luar, pondok pesantren melakukan interview terlebih dahulu agar mengetahui seperti apa karakter calon santri yang akan masuk ke pondok pesantren. Biasanya tes interview dilakukan oleh para ustadz dan ustadzah agar pada saat nanti mereka mendampingi dan membimbing dalam suatu kegiatan, sang ustadz dan ustadzah telah memahami bagaimana harus menghadapi santri tersebut. Beberapa kendala yang dihadapi biasanya adalah sebagai berikut: (1) Latar belakang pendidikan santri sebelumnya sangat variatif, sehingga pemahaman nilai-nilai keislamannya sangat beragam (2) Latar belakang keluarga santri yang berbeda-beda ini mempengaruhi sikap, kedisiplinan dan kepatuhan santri di pondok pesantren (3) Kurangnya kesadaran santri tentang pendidikan karakter (4) Santri gampang terbawa arus karena usianya masih labil (5) Santri banyak menyerap hal-hal negatif dari media khusunya internet akibat dari adanya pengaruh budaya dan arus informasi global (6) adanya pencurian dan kehilangan yang dialami santri. Seperti yang dibarkan tabel berikut :

Pesantren menerapkan beberapa peraturan agar metode praktik dan metode keteladanan dapat diserap secara maksimal oleh santri, yakni santri tidak diizinkan untuk membawa telepon genggam ke dalam pondok pesantren dan memainkan sosial media seperti facebook dan lain sebagainya. Dengan adanya peraturan tersebut diharapkan pendidikan karakter dapat berjalan dengan maksimal dan karakter santri yang telah dibangun di dalam pondok pesantren tidak cepat terpengaruh oleh pergaulan luar yang terkadang membawa pengaruh buruk dalam diri santri. Hal tersebut juga didukung oleh wali santri yang menginginkan karakter anakanak mereka menjadi lebih baik. Dalam hal ini selain pengurus pondok pesantren, wali santri juga ikut terlibat dalam pelaksanaan pendidikan karakter. Wali santri tidak secara langsung lepas tangan setelah memasukkan anak-anak mereka kedalam pondok pesantren, akan tetapi mereka tetap mengawasi pelaksanaan pendidikan karakter pada anak-anak mereka.

Peran serta wali santri di pondok pesantren juga dibutuhkan guna mencapai keberhasilan pendidikan karakter santri di dalam pondok pesantren melalui motivasi dan dukungannya. Sebagai pihak keluarga yang memiliki andil besar dalam pembentukan karakter santri, wali santri diizinkan untuk mengunjungi santri setiap saat ketika santri tidak sedang mengikuti kegiatan yang ditetapkan pondok pesantren. Dalam hal ini wali santri tetap dapat mendidik dan menasihati santri agar penanaman pendidikan karakter dapat lebih meresap dalam diri santri.

Bahan evaluasi dalam pelaksanaan kegiatan dan pembiasaan santri di pondok pesantren disediakan buku presensi. Presensi tersebut digunakan untuk mencatat kehadiran santri sekaligus sebagai bahan memantau santri apabila tidak mengikuti kegiatan. Bagi santri yang tidak mengikuti kegiatan akan dikenakan hukuman sesuai dengan pelanggaran yang dilakukan oleh santri. Hukuman tersebut diberikan karena setiap kegiatan yang ditetapkan oleh pondok pesantren diwajibkan kepada seluruh santri dan sebagai wujud melatih keteladaan pada diri santri itu sendiri.

Bentuk pembinaan pendidikan karakter di Pesantren Persis 67 Benda Tasikmaaya dianggap penting untuk dimiliki santri sebab terdapat beberapa fenomena yang dihadapi di Pesantren ini, di antaranya: Pertama, pesantren ini pernah mengalami perubahan orientasi setelah adanya pengaruh buruk dari kalangan santri kalong yang menggunakan NAPZA (narkotika penggunaan zat adiptif) sehingga pihak pesantren memberlakukan semua santri untuk diasramakan (boarding). Perubahan ini berimplikasi pada hampir separuh dari santrinya memilih untuk pindah karena menolak diasramakan di lingkungan pesantren. Kedua, tindakan pencurian, merokok, membawa alat komunikasi handpone, dan malas kerap ditemukan di kalangan santri sehingga membuat keresahan di lingkungan pesantren. Tindakantindakan seperti ini dapat menurunkan martabat santri dan pesantren. Ketiga, upaya penegakan hukum (law enforcement) yang biasa diterapkan di pesantren mengalami perubahan orientasi setelah 
serentetan peristiwa pelanggaran HAM (Hak Asasi Manusia) banyak ditemukan di Indonesia. Kasus yang paling besar bagi perubahan mekanisme penegakan hukum di Pesantren Persis adalah kasus pelanggaran HAM oleh mahasiswa STPDN (Sekolah Tinggi Pemerintahan Dalam Negeri).

Hubungan santri dengan santri juga menunjukkan suasana yang edukatif. Sesama santri saling berkawan, berolahraga bersama dengan ketentuan-ketentuan yang berlaku, saling mengajak dan diajak, saling bercerita, saling mendisiplinkan diri agar tidak menyinggung perasaan teman sepergaulannya. Dalam lingkungan sekolah seorang individu dihadapkan pula pada pola orientasi kehidupan yang lebih luas. Perangkat-perangkat aktivitas tersebut tidak dia temui di dalam keluarga. Secara prinsipil melihat sekolah sebagai ruang terorganisasi yang di dalamnya terdapat peranperan yang cukup kompleks maka seluruh siswa telah balajar mengenal orientasi kehidupan menuju pembelajaran dan persiapan untuk menyandang status orang-orang dewasa.

\section{PENUTUP}

Pola pendidikan karakter di Pesantren Persis 67 Benda berporos pada proses pengajaran, pembasaan, dan penegakkan aturan. Proses pengajaran menghasilkan suatu model yang memberikan pengembangan bukan hanya pada aspek kurikulum yang menggabungkan antara muatan kurikulum kementerian agama dan muatan kementerian pendidikan nasional, namun juga memuat muatan lokal. Semuata kurikulum yang ada tersebut harus mengandung prinsip-prinsip yang diterapkan, antara lain: Prinsip relevansi (kedekatan hubungan antara materi pembelajaran dan fenomena yang ada). Kedua, prinsip fleksibilitas. Prinsip ini mengandung makna bahwa kurikulum yang dikembangkan harus memiliki ruang gerak yang menyediakan kebebasan dalam bertindak, memilih program pendidikan, dan pengembangan program pembelajaran. Ketiga, prinsip efisiensi yang menyangkut biaya, usaha, waktu, dan tenaga. Keempat, prinsip efektivitas, prinsipini lebih dirientasikan pada perencanaan kurikulum dapat dicapai sesuai dengan keinginan yang telah ditentukan. Kelima, prinsip kesinambungan dengan menunjukkan adanya hubungan antara tingkat pendidikan, jenis pendidikan, dan bidang studi. Dari tiga model pengembangan tersebut, pembiasaan menjadi inti (core) bagi model pengembangan karakter di pesantren persis 67 Benda. Upaya pembiasaan karakter/akhlak dalam kehidupan santri memiliki peran dalam membangun pemahaman, sikap, kecerdasan, perasaan serta perilaku santri. Pembiasaan karakter santri tidak semata-mata untuk memperluas pengetahuan santri dengan penjelasan-penjelasan, tetapi untuk meningkatkan akhlak, melatih dan mempertinggi motivasi, menghargai nilai-nilai spiritual dan humanisme, mengajarkan sikap dan tingkah-laku yang disiplin, jujur dan bermoral, serta menyiapkan para santri belajar mengenai etika. Dalam pembiasaan ini terdapat upaya yang dilakukan berupa internalisasi yang mengedepankan nilai kemandirian, nilai tanggung jawab, dan nilai religious yang disosialisasi melalui bentuk demontrasi, gambar, verbal, dan praktikal.

Sementara penegakkan aturan diimplementasikan guna memberikan sanksi fisik, melainkan lebih bersifat motivasi bagi santri. Pada aspek penegakkan aturan, pihak pesantren menerapkan beberapa peraturan agar metode praktik dan metode keteladanan dapat diserap secara maksimal oleh santri. Hal tersebut juga didukung oleh wali santri yang menginginkan karakter anak-anak mereka menjadi lebih baik. Penegakan aturan diorientasikan guna menanamkan nilainilai kebiasaan-kebiasaan yang baik yang dilandasi oleh model motivasional, bukan model sanksi pisik. Implementasi penegakan aturan berbasis model sanksi motivasional ini diorientasikan untuk menekankan tumbuhnya (1) pengetahuan yang baik (2) perasaan yang baik dan (3) prilaku yang baik.

tertumpu pada 3 (tiga) proses pendidikan, antara lain: Aspek pengajaran, aspek pembiasaan, dan aspek penegakkan aturan. Pada aspek pengajaran, pengembangan karakter terlihat dari model yang dikembangkannya berupa pengajaran bersifat egaliter dan terbuka. Egaliter terkonstruk pada model interaksi dan komunikasi antara ustadz dan santri yang membuka model two way interaction. Pada model ini santri dan ustadz lebih bersifat interaktif. Bahkan santri dapat memberi masukan dan menyanggah penjelasan yang diberikan oleh ustadz sehingga modelnya bersifat resiprokal (saling mengkoreksi).

\section{UCAPAN TERIMA KASIH}

Tulisan yang sidang pembaca baca ini tidak terlepas dari kontribusi berbagai pihak, antara lain: Para ustadz dan santri di lingkungan Pesantren Persis 67 Benda Tasikmalaya Jawa Barat. Ucapan 
terima kasih juga disampaikan kepada Dr. Sarbini yang telah berkontribusi dalam kegiatan penelitan ini.

\section{PUSTAKA}

Azra, Azyumardi. 2008. Pendidikan Islam: Tradisi dan Modernisasi Menuju Milenium Baru. Jakarta: Penerbit Kalimah.

Dhofier, Zamakhsyari. 2011. Tradisi Pesantren: Studi Tentang Pandangan Hidup Kyai. Jakarta: LP3ES.

Departemen Agama Republik Indonesia. 2010). Sistem Pendidikan Nasional. Jakarta: Direktoran Pendidikan Diniyah dan Pondok Pesantren.

Djatnika, Racmat. 1996. Sistem Ethika Islami. Jakarta: Pustaka Panjimas.

Gintings, Abdorrakhman. 2010. Esensi Praktis Belajar \& Pembelajaran. Bandung: Humaniora.

Hasanah, Aan. 2012. Pendidikan Karakter Berprespektif Islam. Bandung: Penerbit Insan Komunika.

-. 2011. Pendidikan Karakter Berbasis

Islam. Disertasi. Bandung: UIN Sunan Gunung Djati.
Lickona, T. 1992. Educating for Character: How Our School Can Teach Respect and Responsibility. New York: Simon \& Schuster, Inc.

Kementerian Pendidikan Nasional. 2010. Pengembangan Pendidikan Budaya dan Karakter Bangsa Pedoman Sekolah. Jakarta: Puskur Balitbang Kemendiknas.

Keputusan Direktorat Jenderal Pendidikan Dasar dan Menengah Departemen Pendidikan Nasional Nomor 226/C/Kep/0/1992.

Majid, Abdul. 2012. Pendikan Karakter Persfektif Islam. Bandung: Rosda.

Muslich, Masnur. 2011. Pendidikan Karakter (Menjawab Tantangan Krisis Multidimensional). Jakarta: Bumi Aksara.

Nasir, Mohammad, 1988, Metode Penilitan. Jakarta: Ghalia Indonesia.

Sarbini. 2017. Optimalisasi Pendidikan Karakter, Disertasi, Bandung: UIN Sunan Gunung Djati.

Tafisr, Ahmad. 1991. Ilmu Pendidikan dalam Perspektif Islam. Bandung: Remaja Rosda Karya.

1990. Filsafat Umum. Bandung: Remaja Rosdakarya. 